\title{
Meningkatkan KeterampilanMenulis Mahasiswa dengan Pemanfaatan Learning Management System (LMS) STMIK Handayani di Era Pandemi
}

\author{
${ }^{1}$ Nurfaedah \\ ${ }^{2}$ Nurmadina
}

\author{
12STMIK Handayani, Indonesia \\ ${ }^{1}$ nurfaedahakimya@handayani.ac.id; \\ 2nurmadinahs@handayani.ic.id
}

\begin{abstract}
Abstrak
Penelitian ini bertujuan mengetahui bagaimana media Learning Management System (LMS) meningkatkan kemampuan menulis mahasiswa STMIK Handayani di era pandemi. Penelitian ini meupakan penelitian tindakan kelas (PTK). Metode pengumpulan data adalah metode observasi. Teknik pengumpulan data yaitu dengan menggunakan teknik wawancara, pemberian soal serta pendokumentasian. Analisis data dlakukan dengan 5 kali pertemuan setiap siklus dengan lanjutan analisis setiap siklus kegiatan. Hasil penelitian menunjukkan bahwa aplikasi LMS yang digunakan sebagai media pembelajaran dapat meningkatkan keterampilan menulis proposal mahasiswa STMIK Handayani di era pandemi. Dari hasil observasi yang dilakukan selama 2 siklus dengan menggunakan LMS, memberi banyak perubahan pada mahasiswa. Dalam pembelajaran menulis menggunakan LMS terbukti dapat meningkatkan kemampuan menulis mahasiswa. Hal ini dapat dilihat dari siklus I yang ketuntasan belajarnya hanya mencapai $42 \%$ dengan rata-rata 61,49 kemudian naik menjadi $94 \%$ pada siklus II dengan rata-rata 82,22 .
\end{abstract}

Kata Kunci: keterampilan menulis, LMS, era pandemic

\begin{abstract}
The study aims to find out how the Learning Management System (LMS) media improves the writing skills of STMIK Handayani students in the pandemic era. The research is a classroom action research (CAR). The data collection method is the observation method. The Data collection techniques are interview technique, giving questions and documentation. The data analysis was carried out in 5 meetings in each cycle and then analyzing the activity in each cycle. The results showed that the LMS application that was used as a learning medium could improve the students' proposal writing skills of STMIK Handayani in the pandemic era. The results of observations in 2 cycles by using the LMS, the students ability in writing improved. Learning writing by using LMS could improve students' writing skills. It was obtained in the first cycle where the learning completeness only reached $42 \%$ with an average of 61.49 then increased to $94 \%$ in the second cycle with an average of 82.22 .
\end{abstract}

Keywords : writing skills, LMS, pandemic era 


\section{Pendahuluan}

Di era pandemi covid-19 yang terjadi di Indonesia sejak 30 Januari 2020 memberikan pengaruh kuat yang cukup berarti terhadap sistem kehidupan masyarakat tak terkecuali terhadap sistem pendidikan yang berlaku selama ini. Untuk mencegah penyebaran virus covid-19 banyak tempat yang dilarang beroperasi seperti biasanya termasuk lembaga pendidikan. Sebagai bentuk tindak lanjut dari ditutupnya lembaga pendidikan maka proses pembelajaran yang selama ini dilakukan secara tatap muka (offline) berubah dan diganti menjadi pembelajaran online. Segala bentuk kegiatan yang dapat mengumpulkan orang banyak dibatasi dan semua orang dianjurkan untuk berdiam di rumah.

Perkembangan teknologi informasi memberikan kesempatan untuk memformulasikan dan menggunakan program komputer dalam pembelajaran yang berorientasi pada peningkatan kemampuan mahasiswa dalam proses pembelajaran yang berubah drastis. Dalam hal pengembangan kemampuan mahasiswa terampil dalam menulis maupun berbicara, pengajaran mahasiswa perlu dilatih melalui keterampilan berbahasa yang meliputi mendengarkan, berbicara, membaca, dan menulis. Keterampilan berbahasa diberikan dalam satu rangkaian namun dimungkinkan untuk ditekankan pada salah satu keterampilan yang paling sering digunakan. Dalam penelitian ini yang menjadi fokus pembahasan adalah keterampilan menulis.

Dalam hubungannya dengan kemampuan menulis, di era pandemi ini sangat dibutuhkan media yang mampu menunjang peningkatan proses belajar mengajar yang saat ini tidak bisa dilakukan melalui proses tatap muka. Konsep pendidikan pada saat ini telah mengalami perubahan dari model pembelajaran pasif menjadi model pembelajaran aktif yang memungkinkan pembelajar dapat dilibatkan langsung dalam proses pembelajaran baik secara mental maupun fisik dalam keseluruhan rangkaian prosesnya. Karenanya para pelaku pendidikan dalam hal ini pengajar senantiasa diharapkan untuk mengimplementasikan konsep pembelajaran yang dapat melibatkan pembelajar secara aktif serta mampu berinteraksi dengan baik dengan rekan maupun perangkat-perangkat pembelajaran yangdisajikan.

Salah satu aplikasi pembelajaran jarak jauh yang dapat dikembangkan oleh para pendidik, khususnya di perguruan tinggi adalah Learning Management System, yang salah satu jenisnya adalah Moodle. Moodle adalah salah satu platform yang digunakan untuk menunjang sistem manajemen pembelajaran secara online dan menggunakan perangkat komputer dan gadget. Moodle juga termasuk ke dalam aplikasi berbasis web (web-based) yang setiap aktivitas pembelajaran terkait akses materi, diskusi, tanya jawab, hingga evaluasi dapat dilakukan melalui tampilan website dengan menggunakan bantuan browser. Hasil pengembangan Moodle selanjutnya dapat diakses oleh mahasiswa denganmemanfaatkan jaringan internet.

Olehnya, peneliti berusaha untuk memanfaatkan media Learning Management System (LMS) berbasis Moodle sebagai bentuk inovasi pembelajaran dengan melibatkan perkembangan teknologi untuk mengetahui sejauh mana proses 
keterampilan menulis mahasiswa bisa ditingkatkan melalui daring. Media ini akan digunakan untuk mengukur seberapa efektif media ini dapat diterapkan dalam meningkatkan kemampuan menulis mahasiswa di STMIK Handayani di era pandemi. Melalui penggunaan e-learning selama kegiatan perkuliahan, perubahan sikap mahasiswa untuk memanfaatkan internet sebagai salah satu sumber belajar diharapkan dapat meningkat.

\section{Kerangka Teori}

Pengertian Menulis

Menurut Maslakhah (2005), menulis adalah berkomunikasi untuk mengungkapkan pikiran, gagasan, perasaan, dan kehendak kepada orang lain secara tertulis. Selanjutnya, Djibran (2008:17) menyatakan bahwa menulis adalah mengungkapkan pikiran, perasaan, pengalaman, dan hasil bacaan dalam bentuk tulisan, bukan dalam bentuk tutur.

Selanjutnya, menurut Nurgiyantoro (2012), dilihat dari kompetensi berbahasa, menulis adalah aktivitas aktif produktif, aktivitas menghasilkan bahasa, sedangkn secara umum, menulis adalah aktivitas mengemukakan gagasan melalui media bahasa.

Berbeda halnya dengan Semi (2017) yang menyatakan bahwa menulis merupakan suatu proses kreatif memindahkan gagasan ke dalam lambing-lambang tulisan, yang harus memperhatikan tiga aspek utama yaitu adanya tujuan atau maksud tertentu yang hendak dicapai, adanya gagasan atau sesuatu yang hendak dikomunikasikan, dan adanya sistem pemindahan gagasan itu yang berupa sistem bahasa.

Lebih lanjut menulis menurut Gie (2002) diistilahkan mengarang, yaitu segenap rangkaian kegiatan seseorang untuk mengungkapkan gagasan dan menyampaikannya melalui bahasa tulis kepada masyarakat pembaca untuk dipahami. Dalam kehidupan modern ini, jelas bahwa keterampilan menulis sangat dibutuhkan. Menulis dipergunakan seseorang untuk mencatat atau merekam, meyakinkan, melaporkan atau memberitahukan, dan mempengaruhi orang lain. Maksud dan tujuan seperti itu hanya dapat dicapai dengan baik oleh orang-orang yang dapat menyusun pikirannya dan mengutarakannya dengan jelas, kejelasan ini tergantung pada pikiran, organisasi, dan pemakaian kata-kata yang jelas dan baik.

Manfaat Menulis

Menulis itu penting dan besar kegunaannya bagi kehidupan seseorang. Akhadiah (1997) mengemukakan bahwa kegiatan menulis memiliki banyak manfaat antara lain sebagai berikut:

a. Menulis menyumbang kecerdasan

Dalam hal ini dengan menulis seseorang dapat mengenali kemampuan dan potensi dirinya. Ia dapat mengetahui batas pengetahuan yang dimilikinya tentang suatu topik. Untuk mengembangkan topik itu, seseorang harus berpikir, menggali pengetahuan dan pengalaman yangkadang kala tersimpan di alam bawah sadar.

b. Menulis mengembangkan daya inisiatif dan kreatif Maksudnya melalui kegiatan menulis, seseorang dapat mengembangkan gagasannya.

c. Menulis menumbuhkan keberanian 
Kegiatan menulis memaksa seseorang lebih banyak menyerap, mencari serta menguasai informasi yang berhubungan dengan topik yang akan ditulis.

d. Menulis mendorong kemauan dan kemampuan mengumpulkan informasi

Menulis berarti mengorganisasikan gagasan secara sistematik serta mengungkapkannya secara tersurat. Melalui tulisan, seseorang dapat meninjau serta menilai gagasannya secara lebih objektif. Kegiatan menulis yang terencana akan membiasakan seseorang berpikir dan berbahasa yang tertib.

\section{Learning Management System (LMS)}

Learning Management System (LMS) adalah sebuah alat untuk menunjang ELearning. LMS adalah paket perangkat lunak yang digunakan untuk mengelola satu atau lebih peserta didik. LMS dapat digambarkan sebagai suatu sistem perangkat lunak berbasis server yang digunakan untuk megelola pembelajaran dan mengirimkan semua materi dengan berbagai jenis bentuk data baik berupa teks, audio maupun video. (Mardiana, 2019)

Menurut Coates, dkk (2005) LMS dapat didefinisikan sebagai suatu sistem berbasis internet yang mengintegrasikan antara pedagogik dan administrasi pembelajaran. Ayub, dkk (2010), menyatakan LMS adalah sebuah sistem teknologi berbasis web yang dapat membantu perencanaan, distribusi dan evaluasi proses pembelajaran.

\section{Metode}

\section{Lokasi Penelitian}

Lokasi penelitian ini akan dilaksanakan di kampus STMIK Handayani Makassar bertempat di Jl. Adhyaksa Baru No.1. Pemilihan lokasi penelitian di STMIK Handayani Makassar dikarenakan kampus STMIK merupakan salah satu kampus yang berbasis IT dimana mahasiswa terbiasa berinterkasi dengan computer. Pemanfaatan media di era pandemi baru saja diterapkan di kampus ini sehingga bisa menjadi acuan untuk peneliti dalam hal melihat peningkatan hasil belajar mahasiswa dalam hal menulis dengan menggunakan Learning Management System (LMS).

\section{Desain Penelitian}

Penelitian ini merupakan penelitian tindakan kelas (PTK) dengan menggunakan media Learning Management System (LMS). Penelitian tindakan kelas adalah penelitian yang dilakukan oleh pendidik di dalam kelasnya sendiri melalui refleksi diri, dengan tujuan untuk memperbaiki kinerjanya sebagai pendidik, sehingga hasil belajar peserta didik meningkat (Wardhani dan Wihardit, 2016). Penelitian ini dilakukan dengan dua siklus. Setiap siklus terdiri dari dua pertemuan. Masing-masing siklus terdiri dari empat tahap, yaitu tahap perencanaan, tahap pelaksanaan, tahap pengamatan dan tahap refleksi. 
Gambar 1.

Bagan Alir Penelitian Tindakan Kelas

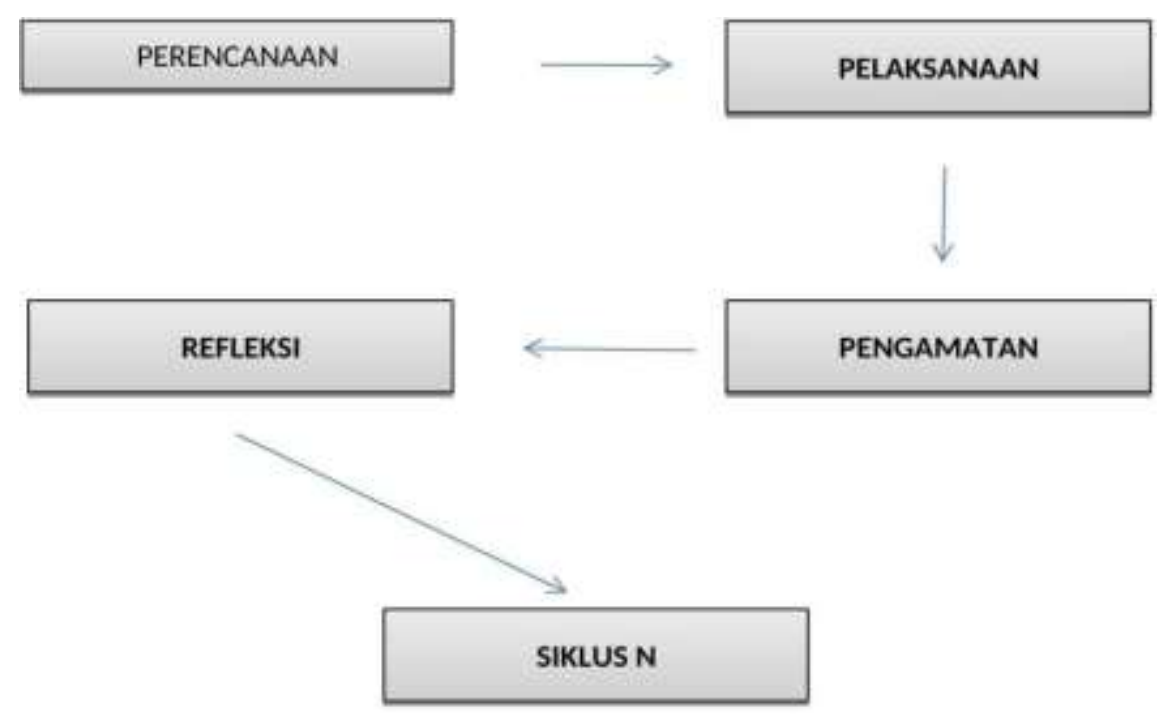

Berdasarkan alur gambar diatas langkah penelitian tindakan kelas terdiri atas :

a. Perencanaan

Pada tahap ini peneliti mempersiapkan rencana pelaksanaan penggunaan Learning Management System (LMS):

1. Tim menyiapkan rencana perkuliahan dengan menggunakan media LMS

2. Tim menetapakan indikator keberhasilan tindakan

3. Tim menyusun topik dan bahan mengenai menulis serta panduan untuk mengaksesLMS.

b. Pelaksanaan

Pelaksanaan tindakan dilakukan dalam 5 kali pertemuan. Tahap pelaksanaan tindakandilakukan oleh peneliti dan tim dalam menerapkan media LMS.

c. Pengamatan

Pengamatan dilakukan pada saat proses perkuliahan berlangsung. Adapun yang diamatiadalah sebagai berikut:

1. Mengamati aktifitas mahasiswa

2. Mengamati hasil kerja mahasiswa pada media LMS

d. Refleksi

Pada tahap ini peneliti melakukan evaluasi dari pelaksanaan tindakan pada siklus, meliputi analisis, sintesis, pemaknaan, penjelasan dan penyimpulan data dan informasi yang berhasil dikumpulkan. Data dan informasi tersebut digunakan sebagai bahan kesimpulan untuk hasil yang diharapkan. Jika hasil yang diharapkan belum terpenuhi maka dilakukan perbaikan pada pelaksanaan siklus selanjutnya. Siklus selanjutnya dilaksanakan jika peserta didik belum menunjukkan peningkatan dalam hal keterampilan menulis. 


\section{Hasil}

\section{Hasil Tes Kemampuan Menulis Mahasiswa Siklus I}

Berdasarkan hasil analisis deskriptif sebagaimana yang tercantum pada lampiran-lampiran, maka rangkuman skor hasil belajar mahasiswa pada Siklus I yang dikelompokkan ke dalam 5 kategori maka diperoleh tabel frekuensi skor yang ditunjukkan pada tabel berikut:

\section{Tabel 1: Distribusi Frekuensi dan Persentase Skor Tes Kemampuan Hasil Menulis} Mahasiswa Siklus I

\begin{tabular}{|c|c|c|c|c|}
\hline No. & Skor & Kategori & Frekuensi & Persentase \\
\hline 1. & $0-34$ & Sangat Rendah & 3 & $8 \%$ \\
\hline 2. & $35-54$ & Rendah & 9 & $25 \%$ \\
\hline 3. & $55-64$ & Sedang & 3 & $8 \%$ \\
\hline 4. & $65-84$ & Tinggi & 21 & $58 \%$ \\
\hline 5. & $85-100$ & Sangat Tinggi & - & $0 \%$ \\
\hline \multicolumn{3}{|c|}{ Jumlah } & 36 & 100 \\
\hline
\end{tabular}

Hasil Tes Kemampuan Menulis Mahasiswa pada Siklus II

Dari analisis skor hasil tes menulis mahasiswa setelah diterapkan penggunaan LMS selama siklus II, maka hasil tes menulis jika dikelompokkan ke dalam kategori 5 dapat dilihatpada tabel distribusi frekuensi sebagai berikut:

Tabel 2 :Distribusi Frekuensi dan Persentase Skor Tes Kemampuan Menulis Mahasiswa Siklus II

\begin{tabular}{|c|c|c|c|c|}
\hline No. & Skor & Kategori & Frekuensi & Persentase \\
\hline 1. & $0-34$ & $\begin{array}{c}\text { Sangat } \\
\text { Rendah }\end{array}$ & 0 & $0 \%$ \\
\hline 2. & $35-54$ & Rendah & 0 & $0 \%$ \\
\hline 3. & $55-64$ & Sedang & 2 & $6 \%$ \\
\hline 4. & $65-84$ & Tinggi & 17 & $47 \%$ \\
\hline 5. & $85-100$ & Sangat Tinggi & 17 & 100 \\
\hline \multicolumn{2}{|c|}{ Jumlah } & 36 & \\
\hline
\end{tabular}

\section{Hasil Observasi Kegiatan Belajar Mahasiswa}

Berdasarkan hasil observasi selama berlangsungnya penelitian dari Siklus I dan Siklus II tercatat sejumlah perubahan. Perubahan yang terjadi pada sikap mahasiswa terhadap materi yang disajikan pada LMS. Perubahan tersebut merupakan data yang diperoleh dari lembar observasi pada setiap siklus tercatat oleh guru selama penelitian.

Siklus I

Pada Siklus I, proses pembelajaran dilakukan dengan menggunakan LMS, mahasiswa belum bisa mengikuti pembelajaran dengan baik. Hal ini disebabkan mahasiswa belum terbiasa dan masih bingung dengan penggunaan LMS. Adapun hasil observasi mahasiswa pada Siklus I dapat dilihat dari tabel berikut ini: 
Tabel 3: Deskripsi Persentase Observasi Kegiatan Belajar Mahasiswa pada Siklus I

\begin{tabular}{|c|l|c|c|}
\hline \multirow{2}{*}{ No. } & \multicolumn{1}{|c|}{ Aspek Yang Diamati } & \multicolumn{2}{|c|}{ Siklus I } \\
\cline { 3 - 4 } & \multicolumn{1}{|c|}{$\begin{array}{c}\text { Mahasiswa yang memperhatikan penjelasan } \\
\text { pada LMS }\end{array}$} & 22 & $61 \%$ \\
\hline 1. & Kualitas dan ruang lingkup judul & 19 & $53 \%$ \\
\hline 3. & Organisasi (struktur) dan penyajian isi & 22 & $61 \%$ \\
\hline 4. & Gaya dan bentuk bahasa & 27 & $75 \%$ \\
\hline 5. & Ejaan dan tanda baca & 26 & $72 \%$ \\
\hline
\end{tabular}

Siklus II

Setelah Siklus I berakhir dan dilanjutkan dengan Siklus II mahasiswa tidak lagi mengalami ketegangan dalam proses pembelajaran menulis dengan menggunakan LMS, baik itu pada saat pembelajaran berlangsung maupun pada saat pemberian tugas menulis. Adapun hasil observasi mahasiswa pada siklus II dapat dilihat pada tabel berikut:

Tabel 4: Deskripsi Persentase Hasil Observasi Kegiatan Belajar Mahasiswa pada Siklus II

\begin{tabular}{|c|l|c|c|}
\hline \multirow{2}{*}{ No. } & \multicolumn{1}{|c|}{ Aspek Yang Diamati } & \multicolumn{2}{|c|}{ Siklus I } \\
\cline { 3 - 4 } & \multicolumn{1}{|c|}{ Frekuensi } & Persentase \\
\hline 1. & $\begin{array}{l}\text { Mahasiswa yang memperhatikan penjelasan pada } \\
\text { LMS (materi dan video) }\end{array}$ & 34 & $90 \%$ \\
\hline 2. & Kualitas dan ruang lingkup judul & 34 & $90 \%$ \\
\hline 3. & Organisasi (struktur) dan penyajian isi & 32 & $89 \%$ \\
\hline 4. & Gaya dan bentuk bahasa & 34 & $90 \%$ \\
\hline 5. & Ejaan dan tanda baca & 36 & $100 \%$ \\
\hline
\end{tabular}

\section{Pembahasan}

Hasil Belajar Mahasiswa Siklus I

Dari hasil belajar mahasiswa pada Siklus I dan dianalisis, maka persentase ketuntasan belajar mahasiswa pada Siklus I dapat dilihat pada tabel berikut ini;

Tabel 5: Deskripsi Ketuntasan Belajar Mahasiswa pada Siklus I

\begin{tabular}{|c|c|c|c|}
\hline $\begin{array}{c}\text { Persentase } \\
\text { Skor }\end{array}$ & Kategori & Frekuensi & Persentase \\
\hline $0-64$ & Tidak Tuntas & 15 & $42 \%$ \\
\hline $65-100$ & Tuntas & 21 & $58 \%$ \\
\hline \multicolumn{2}{|c|}{ Jumlah } & 36 & 100 \\
\hline
\end{tabular}

768 
Siklus II

Dari hasil belajar mahasiswa pada Siklus II dan dianalisis, maka persentase ketuntasan belajar mahasiswa pada Siklus II dapat dilihat pada tabel berikut ini:

Tabel 6: Deskripsi Ketuntasan Belajar Mahasiswa Pada Siklus II

\begin{tabular}{|c|c|c|c|}
\hline $\begin{array}{c}\text { Persentase } \\
\text { Skor }\end{array}$ & Kategori & Frekuensi & Persentase \\
\hline $0-64$ & Tidak Tuntas & 2 & $6 \%$ \\
\hline $65-100$ & Tuntas & 34 & $94 \%$ \\
\hline \multicolumn{2}{|c|}{ Jumlah } & 36 & 100 \\
\hline
\end{tabular}

Selanjutnya tabel 7 di bawah ini akan memperlihatkan hasil belajar menulis mahasiswa mengunakan LMS pada Siklus I dan Siklus II.

Tabel 7: Deskripsi Ketuntasan dan Persentase Skor Hasil Tes Kemampuan Menulis Mahasiswa pada Akhir Siklus I dan Siklus II

\begin{tabular}{|c|c|c|c|c|c|c|}
\hline \multirow{2}{*}{ No. } & \multirow{2}{*}{ Skor } & \multicolumn{2}{|c|}{ Frekuensi } & \multicolumn{2}{c|}{ Persentase } & \multirow{2}{*}{ Kategori } \\
\cline { 3 - 6 } & & Siklus I & Siklus II & Siklus I & Siklus II & \\
\hline 1. & $0-34$ & 3 & 0 & $8 \%$ & $0 \%$ & Sangat Rendah \\
\hline 2. & $35-54$ & 9 & 0 & $25 \%$ & $0 \%$ & Rendah \\
\hline 3. & $55-64$ & 3 & 2 & $8 \%$ & $6 \%$ & Sedang \\
\hline 4. & $65-84$ & 21 & 17 & $58 \%$ & $47 \%$ & Tinggi \\
\hline 5. & $85-100$ & - & 17 & $0 \%$ & $47 \%$ & Sangat Tinggi \\
\hline
\end{tabular}

\section{Hasil Observasi Kegiatan Belajar Mahasiswa}

Dari hasil observasi yang dilakukan selama 2 siklus dengan menggunakan LMS, memberi banyak perubahan pada mahasiswa, antara lain:

1. Mahasiswa lebih termotivasi untuk belajar.

2. Keberanian mahasiswa untuk menyelesaikan soal secara individu meningkat. Hal ini ditunjukkan dengan meningkatnya jumlah mahasiswa yang mampu menyelesaikan tugas yang diberikan.

3. Rasa percaya diri mahasiswa meningkat.

4. Mengubah paradigma mengajar menjadi paradigma belajar.

5. Meningkatkan keaktifan dan memotivasi mahasiswa untuk belajar.

Di awal pertemuan banyak kendala yang dihadapi antara lain mahasiswa masih bingung dalam menggunakan LMS, ini berlangsung sampai berakhirnya pelaksanaan Siklus I, maka perbaikan dilaksanakan untuk membenahi pada pelaksanaan Siklus II dengan mengacu pada Siklus I.

Pada Siklus II kendala-kendala yang ditemukan di Siklus I sudah teratasi. Perubahan-perubahan yang terjadi dari Siklus I ke Siklus II antara lain: 
Tabel 10 : Deskripsi Persentase Aktivitas Mahasiswa pada Siklus I dan II

\begin{tabular}{|c|l|c|c|c|c|}
\hline \multirow{2}{*}{ No. } & \multicolumn{1}{|c|}{$\begin{array}{c}\text { Aspek/Indikator } \\
\text { yang Diamati }\end{array}$} & \multicolumn{2}{|c|}{ Siklus I } & \multicolumn{2}{c|}{ Siklus II } \\
\cline { 3 - 6 } 1. & $\begin{array}{l}\text { Mahasiswa yang } \\
\text { memperhatikan } \\
\text { penjelasan pada LMS }\end{array}$ & 22 & $61 \%$ & 34 & $90 \%$ \\
\hline 2. & $\begin{array}{l}\text { Kualitas dan ruang } \\
\text { lingkup judul }\end{array}$ & 19 & $53 \%$ & 34 & $90 \%$ \\
\hline 3. & $\begin{array}{l}\text { Organisasi } \\
\text { (struktur) dan } \\
\text { penyajian isi }\end{array}$ & 22 & $61 \%$ & 32 & $89 \%$ \\
\hline 4. & $\begin{array}{l}\text { Gaya dan bentuk } \\
\text { bahasa }\end{array}$ & 27 & $75 \%$ & 34 & $90 \%$ \\
\hline 5. & $\begin{array}{l}\text { Ejaan dan tanda } \\
\text { baca }\end{array}$ & 26 & $72 \%$ & 36 & $100 \%$ \\
\hline
\end{tabular}

\section{Simpulan}

Berdasarkan hasil penelitian dan pembahasan, maka dapat ditarik kesimpulan bahwa Dalam pembelajaran menulis menggunakan LMS terbukti dapat meningkatkan kemampuan menulis mahasiswa. Hal ini dapat dilihat dari siklus I yang ketuntasan belajarnya hanya mencapai $42 \%$ dengan rata-rata 61,49 kemudian naik menjadi $94 \%$ pada siklus II dengan rata-rata 82,22.

\section{Daftar Pustaka}

Ayub,et. al. (2010). Factors influencing students" use a Learning Management System portal: Perspective from higher education students. International Journal of Education and Information Technologies, 2, 4-8

Coates, H., James, R., \& Baldwin, G. (2005). A critical examination of the effects of learning management systems on university teaching and learning. Tertiary Education and Management, 11, 19-36

Departemen Pendidikan Nasional.2008. Kamus Besar Bahasa Indonesia Edisi Keempat. Jakarta :Diknas.

Djibran, Fahd. 2008. Writing is Amazing. Yogyakarta : Juxtapose

Gie, The Liang. 2002. Terampil Mengarang. Yogyakarta: Andi. 
Mardiana, Novi dan Ahmad Faqih. Pemanfaatan Learning Management System dalam Proses Pembelajaran Matematika Diskrit. Jes-Mat, Vol 5 No 1 Maret 2019

Maslakhah, S. 2005. Menulis Tidak Semudah Membaca dalam Wiedarti, P. \{Ed\}, Menuju Budaya Menulis. Yogyakarta : Tiara Kencana.

Nafiah dan Sri Hartatik. Penerapan Manajemen Pembelajaran Berbasis Daring dengan Menggunakan Aplikasi Google Calssroom untuk Meningkatakan Kemampuan Mahasiswa dalam Membuat Perangkat Pembelajaran. Education and Human Development Journal, Vol 5 No 12020.

Nurgiyantoro, Burhan. 2012. Penialain Pembelajaran Bahasa Berbasis Kompetensi. Yogyakarta : BPFE.

Salam, Husni. 2020. Strategi Menulis Karya Ilmiah Model Pembelajaran Kolaboratif Berbasis Problem Based Learning Pada Mahasiswa Administrasi Bisnis Politeknik Informatika Nasional. Onoma, Vol 6 No 2 November 2020

Sari, Fiqi, N dan Zawaqi, A. Jamil. Peningkatan Kemampuan Menulis Paragraf Mahasiswa Universitas Islam Negeri Sultan ThahaSaifuddin Jambi Menggunakan Media Goolge Classroom. PEJ, Volume I, No. 4 Februari 2020.

Semi, M. Atar. 2007. Dasar-dasar Keterampilan Menulis. Bandung: Angkasa

Wardhani, IG.A.K dan Wihardit, K. 2016. Penelitian Tindakan Kelas. Tangerang Selatan: Universitas Terbuka.

Yana, Dewi dan Adam. Efektifitas Penggunaan Platform LMS Sebagai Media Pembelajaran Berbasis Blended Learning Terhadap Hasil Belajar Mahassiswa. Dimensi, Vol 8 No 1 Maret 2019 